\title{
Коллекция каменных памятников в собрании Национального музея Тувы
}

\author{
Чечена А.-С. Монгуш \\ Национальный музей им. Алдан-Маадыр Республики Тыва, Российская Федерация
}

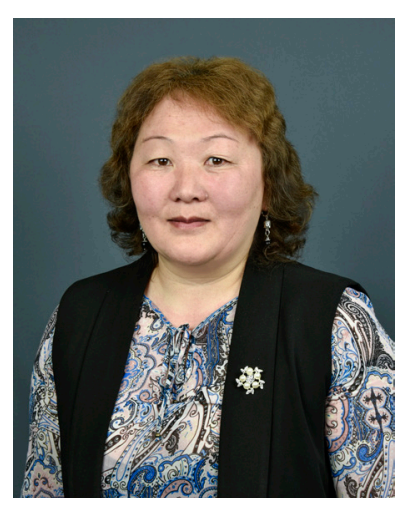

В фондах Национального музея им. Алдан-Маадыр Республики Тыва насчитывается более 160 каменных памятников различных исторических эпох. Все они найдены, в основном, в центральных, южных и западных районах Тувы. Памятники из Тувы также есть в фондах других музеев России и зарубежья.В статье представлена характеристика коллекции, указано время поступления памятников, отмечен вклад ученых-исследователей. Выделены самые интересные памятники, даны их фотографии, примеры надписей, переводы.

Коллекция имеет семь групп памятников: камни с изображениями животных (эпоха бронзы, конец III тысячелетия до н. э. - IX в. до н. э.; оленные камни скифского периода (IX-III вв. до н. э.); каменные антропоморфные изваяния древнетюркского периода (VI-VIII вв.); каменные изваяния древнеуйгурского времени (VIII-IX вв.); стелы с древнетюркской рунической письменностью (IX-XII вв.); каменные памятники периода могущества и расцвета Монгольской империи (начало XIII - конец XIV в.); камни-плиты с тибетскими надписями и на санскрите (конец ХІХ - начало XX в.). В экспозиции представлены 93, остальные расположены в хранилище музея.

Ключевые слова: руническая письменность; памятник древнетюркской рунической письменности; Национальный музей Тувы; древнетюркская культура

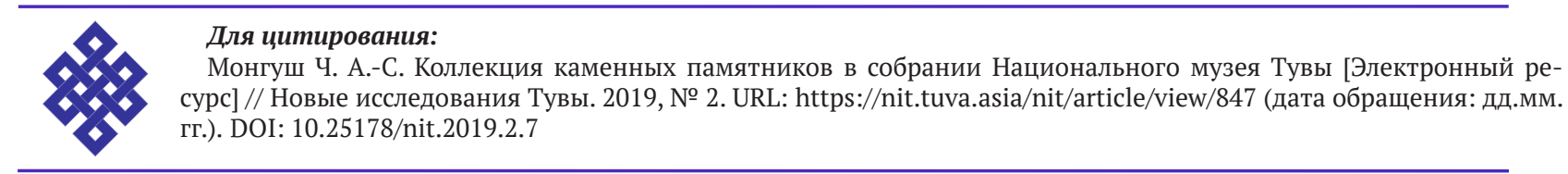

\section{Rock monuments in the collection of the National Museum of Tuva}

\author{
Chechena A.-S. Mongush \\ Aldan-Maadyr National Museum of the Republic of Tuva, Russian Federation
}

The Aldan-Maadyr National Museum of the Republic of Tuva has more than 160 rock monuments of various periods in its collection. They have largely been found in central, eastern and southern rayons of Tuva. Stones and steles from Tuva can also be seen in a number of museums across Russia and abroad. The article provides a description of the collection, including its most interesting pieces, photos, inscription samples (with translation). We also focus on acquisition dates and contributions made by researchers.

The collection can be categorized into seven chronological groups: stones with animal imagery (Bronze Age, late 3rd millennium BCE - 9th century BCE); Scythian deer stones (9th -3rd centuries BCE); Old Turkic stone anthropomorphic figures (6th 8th centuries CE); Old Uighur stone sculptures (8th -9th centuries CE); stelae with runic inscriptions in Old Turkic (9th 12 th centuries CE); rock monuments of the heyday of the Mongolian empire (early 13th - late 14th centuries CE); and the stone slabs with inscriptions in Tibetan and Sanskrit (late 19th - early 20th centuries CE). Of all rock monuments, 93 are permanently featured in the museum's exposition, and the rest are preserved in special collection.

Keywords: runic writing; monuments of Old Turkic runic writing; National Museum of the Republic of Tuva; Old Turkic culture

For citation:

Mongush Ch. A.-S. Rock monuments in the collection of the National Museum of Tuva. The New Research of Tuva. 2019, № 2. URL: https://nit.tuva.asia/nit/article/view/847 (access date: ... ). DOI: 10.25178/nit.2019.2.7

\footnotetext{
: Монгуш Чечена Айыр-Санааевна - заведующая отделом археологии Национального музея им. Алдан-Маадыр Республики Тыва. Адрес: 667000, Россия, г. Кызыл, ул. Рихарда Зорге, д. 313. Тел.: +7 (929) 317-34-73. Эл. адрес: Chechena1@yandex.ru ORCID ID: 0000-0001-7923-3752

Mongush Chechena Ayir-Sanaayevna, Head, Department of Archaeology, Aldan-Maadyr National Museum of the Republic of Tuva. Postal address: 313 Rikhard Zorge St., 667000 Kyzyl, Russian Federation. Tel.: +7 (929) 317-34-73. E-mail: Chechena1@yandex.ru
} 


\section{Введение}

Национальный музей им. Алдан-Маадыр Республики Тыва (НМ РТ) имеет богатую уникальную коллекцию каменных памятников древности, свидетельствующих об истории и особенностях духовной и материальной культуры народов Центральной Азии и Южной Сибири. Они включены в «Государственный каталог музейного фонда РФ» (https://goskatalog.ru/portal/). На сегодняшний день коллекция насчитывает более 160 каменных памятников, отличающихся по виду и содержанию, и относящихся к различным историческим периодам, начиная от эпохи бронзы и до средневековья. Каменные памятники, выполненные искусными мастерами-художниками и каменотесами древности, не теряют своей уникальности и актуальности по сегодняшний день. Они являются высокохудожественными образцами памятников монументального искусства древности, их почитают и продолжают им поклоняться многие современные тюркские народы.

В статье анализируется коллекция каменных памятников, находящихся в тувинском музее ${ }^{1}$. Рассматриваются особенности каждой группы коллекции, техника их выполнения, смысловое содержание. Дается анализ многолетнего наблюдения и фиксирования проявления у современных тувинцев почитания и поклонения каменным памятникам.

При написании статьи автор опиралась на научные труды отечественных ученых: Л. Р. Кызласова (Кызласов, 1969), А. Д. Грача (Грач, 1980), С. И. Вайнштейна (Вайнштейн, 1974), М. А. Дэвлет (Дэвлет, 1990), И. В. Кормушина (Кормушин, 1997, 2008), Д. Д. Васильева (Васильев, 1983), В. А. Семенова, М. Е. Килуновской (Килуновская, Семенов, 1998; Килуновская, 2009).

\section{Комплектование фондов}

Об археологических памятниках Тувы стало известно к началу XVII в. Русские послы неоднократно посещали территорию Тувы. В 1616 г. атаман В. Тюменец и десятник И. Петров, ездившие из Томского острога через Хакасию, Саянский хребет и Туву к западномонгольскому алтын-хану на оз. Убсу-Нур, проезжая по долинам рек Ак-Суга и Хемчика заметили развалины уйгурских крепостей VIII-IX вв. В 1701 г. известный картограф и историк Сибири С. У. Ремезов, по сообщению русских послов, включил в свою составленную «Чертежную книгу Сибири» уйгурскую крепость на острове оз. Тере-Холь (Кызласов, 1969: 5).

В 1915-1916 гг. впервые в истории Тувы, на территории Турано-Уюкской котловины, раскопки проводил археолог-сибиревед из Томска А. В. Адрианов. Материалы раскопок хранятся в Томском государственном университете (Грач, 1980: 10). В конце 1920-х годов исследования в этом же месте проводил известный ленинградский археолог С. А. Теплоухов, находки работы которого поступили в Государственный Эрмитаж (История Тувы, 2014: 5).

В 1929 г. на заседании Политбюро Центрального комитета Тувинской народно-революционной партии (ЦК ТНРП), впервые в Туве, был создан музей - Государственный музей Тувинской Народной Республики (ТНР), который, правда, в течение нескольких лет не имел постоянного подходящего помещения. В 1942 г. музею было передано двухэтажное здание в г. Кызыле по улице Щетинкина-Кравченко, а в 1946 г. Областной исполком трудящихся Тувинской автономной области выделил освободившееся здание по улице Ленина д. 7, где до этого размещался национальный театр (Дыртык-оол, 2006: 14-36). Музей находился в этом здании до февраля 2008 г., затем он переехал в новое здание по ул. Титова, д. 30, где находится и поныне.

Как отмечает А. Д. Грач, в начале 1940 -х годов работу по учету и охране археологических памятников Тувы начал проводить Тувинский республиканский музей. Первым руководителем экспедиции стал командированный из Москвы научный сотрудник Н. М. Богатырев. В 1941 г. экспедиция работала в ПийХемском районе, а в 1942 г. - в Барун-Хемчикском (Грач, 1980: 11-12).

Первая экспедиция 1941 г. была поддержана в районах местными властями. Об этом свидетельствует постановление, принятое в 1942 г. Барун-Хемчикским хошунным комитетом ТНРП и Президиумом хошунного хурала депутатов трудящихся, в котором говорилось о необходимости «взять под особое наблюдение курганы, старинные могилы, пещеры, каменные изваяния, стелы, наскальные изображения, старые места металлообработок, остатки хурээ и других построек» (цит. по: Грач, 1980: 12).

\footnotetext{
${ }^{1}$ Помимо НМ РТ, каменные памятники, найденные в Туве, хранятся, также в других музеях: например, в Минусинском, Абаканском, Красноярском музеях, в Эрмитаже, в Музее антропологии и этнографии АН СССР г. Санкт-Петербурга, в Историческом музее г. Москвы, в Национальном музее г. Хельсинки (Финляндия). А часть памятников продолжает оставаться на местах под открытым небом.
} 
На территории Пий-Хемского района под руководством директора музея Д. Б. Данзын-оола было обследовано тогда 492 кургана. На каждый курган была заведена учетная карточка Института материальной культуры Академии наук СССР по установленной форме. Сотрудники музея находили каменные плиты с надписями и рисунками возле поселков Аржаан и Чкаловка. В дальнейшем они были включены в экспозицию музея (Дыртык-оол, 2006: 31).

Вторая экспедиция Государственного музея ТНР состоялось летом 1942 г. в западных районах: БарунХемчикском, Бай-Тайгинском, Сут-Хольском. Основной задачей ее являлось описание археологических памятников. Отряд также возглавлял директор музея Д. Б. Данзын-оол. Всего было обследовано 103 кургана, множество каменных изваяний, стел с петроглифами (там же: 31).

Тогда же памятники начинают поступать в фонды тувинского музея. Одним из первых поступивших памятников является оленный камень Уюк-Туран, с номером E3, с изображениями животных, древнетюркской рунической надписью и тамгой (фото 1). Камень был обнаружен местным жителем В. П. Фунтиковым в 1886 г. на месте современного города Турана, в 3 км от впадения p. Туран в p. Уюк. Древние изображения животных покрывала тюркская руническая надпись в 6 строк. В паспорте памятника, составленный И. В. Кормушиным в 1993 г., записано, что надпись посвящена герою ОчинКюлюг-тирига и предстает как подробное прощание меморианта не только с супругой, сыновьями, родственниками, государством, ханом, но и с малой родиной - землями на реке Өөк (Уюк), главной рекой Уюкско-Туранской котловины. В тексте упомянуты зятья и невестки, чего нет в некоторых надписях региона. Памятник датирован IX-III вв. до н. э., а надпись - IX-XI вв. Стела была доставлена в музей в 1943 г.

В 1951-1958 гг. в Туве полевые исследования проводила экспедиция Тувинского научно-исследовательского института языка, литературы и истории, руководителем которой был С. И. Вайнштейн. С середины 1950-х гг. и до 1982 г., в Туве работала археологическая экспедиция Московского государственного университета под руководством Л. Р. Кызласова (История Тувы, 2014: 5).

В конце 1950-х - начале 1960-х гг. велись археологические исследования несколькими отрядами. Руководили ими С. И. Вайнштейн, А. Д. Грач, В. П. Дьяконова в составе тувинской комплексной экспедиции, возглавлявшийся Л. П. Потаповым (там же: 5). С 1960 по 1980 гг. археологическую экспедицию Тувинского научно-исследовательского института языка, литературы и истории (ТНИИЯЛИ) возглавлял М. Х. Маннай-оол. Среди объектов исследования был известный царский курган Аржаан. Научный консультант раскопок - ленинградский профессор М. П. Грязнов. В 1974 г. на территории Пий-Хемского района экспедицией ТНИИЯЛИ обнаружены три крупных стелы. Камни были повалены и лежали на посевных площадях в урочище Оорзак, в бассейне р. Уюк. В том же году памятники были доставлены в тувинский музей (Чадамба, Васильев, 1980: 131).

В течение 19 лет, с 1965 по 1984 г. в Туве проводила полевые исследования Саяно-Тувинская экспедиция Ленинградского отделения Института археологии АН СССР (СТЭАН, ныне - Институт истории материальной культуры РАН). Организатором и начальником до 1973 г. был А. Д. Грач, с 1973 по 1984 гг. начальником был С. Н. Астахов (Длужневская, Савинов, 2007: 7-8). В результате исследований на территории зоны затопления в Центральной Туве и Саянском каньоне Верхнего Енисея было изучено и спасено более сотни тысяч объектов археологии. В состав экспедиции входили известные ученые А. Д. Грач, Д. Г. Савинов, Ю. И. Трифонов, С. Н. Астахов, И. У. Самбу, А. М. Мандельштам, Г. В. Длужневская, М. Х. Маннай-оол, В. А. Семенов и многие другие (История Тувы, 2014: 5).

С 1985 г. и по настоящее время на территории Тувы ежегодно работает Тувинская археологическая экспедиция Института Истории материальной культуры РАН г. Санкт-Петербурга, под руководством ученых В. А. Семенова и М. Е. Килуновской. Экспедиция проводит исследования во многих районах республики: Кызылском, Чаа-Хольском, Улуг-Хемском, Овюрском, Пий-Хемском. Изучено десятки могильников, стоянок и много других памятников. Раскопки и исследования проводятся, прежде всего, для спасения исторического наследия в зонах строительства тех или иных объектов.

В результате вышеперечисленных экспедиций в фонды тувинского музея с 1940-х гг. по сегодняшний день поступили более 160 каменных памятников различных эпох, собранных практически со всех районов Тувы. Это оленные камни, стелы с руникой, каменные изваяния, плиты и камни с петроглифами, с тибетскими надписями, камни монгольского периода. Самые многочисленные группы коллекции - оленные камни и каменные изваяния. В экспозиции музея представлены 93 различных камней, из них 18 изваяний и оленных камней установлены по периметру здания. Остальная часть хранятся в хранилище. 
НОВЫЕ ИССЛЕДОВАНИЯ ТУВЫ

www.nit.tuva.asia

Коллекция камней с каждым годом пополняется. В последние годы, в основном, поступают оленные камни, которые музей принимает от Тувинской археологической экспедиции Института Истории материальной культуры РАН г. Санкт-Петербурга (ИИМК РАН), под руководством ученых В. А. Семенова и М. Е. Килуновской. За последние два года в фонды музея экспедицией, совместно с сотрудниками музея, сданы 9 оленных камней с Саглынской долины Овюрского района, которые находились вблизи автомобильной дороги.

\section{Общая характеристика памятников музея}

В коллекции тувинского музея насчитывается 7 групп камней, каждая из которых уникальна и своеобразна по своему выполнению, семантике и содержанию.

K эпохе бронзы (конец III тысячелетия до н. э. - IX в. до н. э.) относятся камни с изображениями животных. На них присутствуют композиции, в которых представлены хищники, преследующие копытных. Кроме этого, в экспозиции есть камни с рогатыми личинами, доказывающие существование в то время шаманов - проводников между мирами людей и духов (Дэвлет, 1990: 3).

Материалом для древних художников служили небольшие камни - валуны округлой, неправильной формы, светло-зеленого, серого, серо-розового, черного оттенков. Изображения выполнялись обычно в технике точечной выбивки острым металлическим инструментом. Это небольшая группа камней, всего их 4 ед. в экспозиции. Они привезены из Овюрского района, из м. Догээ-Баары, из урочища Бедилиг-Аксы, в 5 км выше устья р. Чинге. В музей доставлены в 1970-е годы членами экспедиции СТЭАН .

Следующая группа памятников датируется скифским периодом (IX-III вв. до н. э.). К ним относятся оленные камни, обнаруженные в центральных, южных и западных районах республики. На сегодня их в музее более 40 единиц хранения, это самая большая группа камней. Они представляют собой четырехгранные, овальные в сечении камни, с высотой от 1 до 3,5 м.

Свое название камни получили, соответственно, по изображенным на них фигур оленей. Памятники устанавливались вблизи скифских могильников, у поминальных сооружений. Оленные камни, сохраняющие иногда антропоморфные черты, являлись изображениями первопредка, медиатора, осуществляющего связи между миром живых и мертвых (Килуновская, 2009: 64). Как считает М. Е. Килуновская, оленные камни делятся на 4 типа: 1) общеевразийский - на них выбивались только гривна и пояс, на некоторых оружие. На камнях средними размерами, сверху выбита широкая полоса-диадема. Под ней по бокам выбиты большие контурные круги - «серьги». Ниже них цепочка овальных лунок - «ожерелье». На некоторых камнях в нижней части изображены кинжалы и решетчатые рисунки; 2) саяно-алтайский - с реалистичными изображениями животных (маралов, кабанов, лошадей и др.); 3) монголо-забайкальский - с изображениями стилизованных фигур оленей; 4) смешанный тип - где выбиты «серьги», «ожерелья», кинжалы, конские силуэты. Самыми ранними по датировке видами считаются камни монголо-забайкальского типа, где выбиты силуэты оленей с «клювообразными мордами» и ветвистыми рогами, изображенными в «летучем галопе» (Килуновская, 1998: 143-154).

В коллекции музея представлены оленные камни, где размещены силуэты оленей с ветвистыми рогами, направленными вверх к солярному знаку - солнцу. Знаменитый скифский курган «Аржаан-2» (вторая половина VII в. до н. э.) сверху был покрыт многочисленными каменными плитами, на некоторых из них также были изображены олени. Пять из них сейчас экспонируются в «золотом» зале музея. Олень, точнее марал, считался тотемом скифов, это священное солнечное животное, быстроногое как лошадь, олицетворяло движение солнца. Также напомним, что навершием головного убора скифского «царя», погребенного в кургане Аржаан-2, служила золотая фигурка оленя, «стоящего на цыпочках». Под ним на поля головного убора крепились 4 золотые фигурки лежащих лошадей с подогнутыми ногами. В навершии одной из золотых шпилек скифской «царицы» также выполнен «стоящий на цыпочках» олень (его изображение сегодня стало логотипом тувинского музея). Можно предположить, что чем выше изображение оленя, тем оно ближе к солнцу.

Среди коллекции есть своеобразные оленные камни с изображениями животных и других рисунков, покрытые руникой (которые мы отнесли к другой группе, см. далее).

Камни в музей начали поступать с 1943 г., и до сегодняшнего дня коллекция пополняется. В музей сданы членами экспедиций СТЭАН и ИИМК РАН.

Большой интерес в коллекции стелария тувинского музея вызывают каменные антропоморфные изваяния древнетюркского периода, датируемые VI-VIII вв. Всего их 33 единицы. 
Каменные фигуры людей, имеющие местное название кижи-кожээ («человек-камень»), выполнены из различных пород камня: мрамора, сланца, гранита и песчаника (Кызласов, 1969: 29). Они всегда изображают мужчин и преимущественно воинов, это связано с поминальным обрядом. Изваяния умерших воинов мастера-каменотесы украшали изображением наборного пояса, к которому подвешены меч и сабля, иногда кинжал, боевая булава, ножи в ножнах и мешочки с дорожными инструментами, амулетами и огнивом. Их лицам старались придать портретное сходство с умершим, детализируя формы усов, бороды, манеру ношения сережек, иногда, индивидуализируя черты лица и его выражение. Все фигуры изображены держащими в одной руке, обычно в правой, сосуд для питья (там же: 26-30). Каменные изображения воинов с сосудом в руке ставили рядом с их могилой. Сосуд означал участие погибшего воина в поминальном пире, устраиваемом его родственниками и соратниками возле оградок могил. При этом поминающие обращались к нему и «разговаривали» с ним, принося ему жертву в виде кусочков пищи, которую сжигали на жертвенном огне, чтобы умилостивить его душу. Таким образом, считалось, что в поминальном пиру участвует душа умершего воина, получающая пищу и питье через жертвенный огонь (там же: 32-42).

Наличие сережек у некоторых изваяний, подтверждает о том, что, мужчины тоже носили сережки. У каменного изваяния с р. Чыргакы Дзун-Хемчикского р., привезенного Л. Р. Кызласовым в 1962 г., в ушах изображены серьги в виде колец с каплевидными подвесками. Традиция ношения сережек у мужчин древнетюркского периода, берет начало у скифских племен. У «царя» погребенного в известном кургане Аржаан-2, найдена золотая серьга с бирюзовыми вставками, которая сейчас выставлена в экспозиции тувинского музея.

Камни этой группы были обнаружены в центральных, южных и западных районах республики в 1950-1970-е гг. экспедициями А. Д. Грача, Л. Р. Кызласова и др. Как отмечает А. Д. Грач, первые каменные изваяния в центральной Туве были обнаружены в 1881 г. А. В. Адриановым во время его путешествия по Туве и Алтаю (Грач, 1961: 10). Как считают ученые-исследователи Тувы, по количеству обнаруженных каменных изваяний Тува занимает первое место в Саяно-Алтайском нагорье (История Тувы, 2001: 104).

В древнеуйгурское время (VIII-IX вв.) традиция создания мужских каменных изваяний продолжилась. Это были более реалистичные и тщательно изготовленные скульптуры мужчин - памятники особо отличившимся героям-воинам. Изваяния уйгурского времени также отличаются от каменных фигур тюркского периода наличием изображенных особых шапок или кос, рельефно изображенными сосудами, обычно это узкогорлые кувшины на поддонах, которые фигуры держат обеими руками. Они имеют пояса, чаще всего со многими подвесками, среди которых обычны фигурные бляшки с сердцевидными отверстиями. Эти изваяния высекались только из серого гранита. У всех изваяний детально показаны головной убор, шапка-ушанка или прическа (Кызласов, 1969: 82).

Среди каменных изваяний музея представлено одно изваяние данного периода из урочища Шеми УлугХемского района, на котором детально и четко показана прическа с косичкой (кежеге). Об этом памятнике подробно писал С. И. Вайнштейн (Вайнштейн, 1974: 63-67).

В коллекции стелария важное место занимают стелы с древнетюркской рунической письменностью, датируемые IX-XII вв. Камни доставлены в основном из центральных районов Тувы - Улуг-Хемского, Чаа-Хольского, Пий-Хемского и Кызылского. Памятники представляют собой продолговатые каменные стелы высотой от 1 до 3 метров, которые содержат небольшие тексты, состоящие из резных рунических знаков, направленных снизу - вверх. Это памятные надписи в честь каганов и полководцев, их надгробные обращения к своим соплеменникам. В них говорится о богатстве, о военных и государственных заслугах, о скорби усопших по жизни и оставленным родичам (История Тувы, 2014: 102).

Из источников известно, что письменность создана в середине VI в. с образованием государства тюрков-тюкю. Она получила значительное распространение среди аристократического слоя населения (История Тувы, 2014: 103). Этой письменностью пользовались уйгуры (VIII-IX вв.) и енисейские кыргызы (IX-XII вв.) (там же: 149). B VIII-IX вв. местные племена Тувы пользовались енисейским вариантом этой письменности. Письменность была утрачена во времена нашествий монгольских племен (XIII-XIV вв.) (там же: 131). Древнетюркская руническая письменность была расшифрована датским ученым В. Томсеном в 1893 г. (Кормушин, 1997: 4).

Стелы рунической письменности изучались комплексно в числе других объектов древней истории Тувы. Нахождение памятников, их изучение и доставка в фонды музеев осуществлялись рядом известных зарубежных, советских и российских ученых: И. Р. Аспелин, А. В. Адрианов, А. Д. Грач, С. И. Вайнштейн, Л. Р. Кызласов, И. В. Кормушин, Д. Д. Васильев и др. 
НОВЫЕ ИССЛЕДОВАНИЯ ТУВЫ

www.nit.tuva.asia

У каждого памятника свое сокращенное условное обозначение в виде буквы $E$, что означает енисейская письменность тюрков, с порядковым номером (Батманов, Кунаа, 1963: 4).

Перечислим памятники, хранящиеся в тувинском музее: E3 (Уюк-Туран); Е5 (Барык I); Е6 (Барык II); E7 (Барык III); E8 (Барык IV); E14 (Чаа-Холь II); E17 (Чаа-Холь V); E18 (Чаа-Холь VI); E18 (Чаа-Холь VI); E20 (Чаа-Холь VIII); E21 (Чаа-Холь IX); E22 (Чаа-Холь Х); E23 (Чаа-Холь ХІ); E43 (Кызыл-Чыраa I); E44 (КызылЧыраа II); E45 (Кожээлиг-Хову); Е46 (Телээ); Е52 (Элегест II); E53 (Элегест III); E54 (Оттук-Даш III); E59 (Хербис-Баары); E65 (Кара-Булун I); E66 (Кара-Булун II); E70 (Элегест IV или Ир-Холь); Е73 (Ийме); E92 (Демир-Суг); E96 (Хемчик-Бом); Е100 (Баян-Кол); E108 (Уюк-Оорзак I); E109 (Уюк-Оорзак II); E110 (УюкОорзак III); E147 (Ээрбек I); Е149 (Ээрбек II). Всего 33 камня.

Памятники рунической письменности Тувы хранятся и в других музеях страны и зарубежья. В 1877 г. в Минусинске открылся первый краеведческий музей Сибири. Фонды музея пополнился каменными памятниками из Тувы, привезенными А. В. Адриановым (Длужневская, Савинов, 2007: 26). В 1890 г. для каменных стел Минусинской котловины, Тувы и Хакасии там было отстроено специальное здание. На сегодняшний день в музее хранятся 15 памятников из Тувы: Е1 (Уюк-Тарлак); Е2 (Уюк-Аржан); Е4 (ОттукДаш I); E10 (Элегест I); E11 (Бегре); E13 (Чаа-Холь I); E19 (Чаа-Холь VII); E41 (Хемчик-Чиргак); E42 (БайБулун I); E49 (Бай-Булун II); памятники, первоначальное местонахождение неизвестно - E50; E51; E55; E64; E68 (Эль-Бажы); Е69 (Чер-Чарык) (Кормушин, 2008: 90-165; 2009: 27). По данным И. В. Кормушина, в 1888 г., одна стела с надписью под номером E16 (Чаа-Холь IV) из Тувы, была вывезена в Финляндию Й. Р. Аспелиным. Стела сейчас экспонируется в Национальном музее Финляндии, Хельсинки, в хранилище г. Сеппя (Кормушин, 2009: 28). В Государственном Эрмитаже, в числе находок Красноярской экспедиции Ленинградского отделения института археологии АН СССР, хранятся роговая псалия и поясная бляха с тюркскими руническими надписями, которые были найдены в 1971 г. вблизи известного кургана Аржан, в каменном развале наземного сооружения (Васильев, 1983: 15).

Среди памятников енисейской рунической письменности в собрании тувинского музея, выделяются интересные своеобразные стелы, отличающиеся по своему содержанию и характеру. Это оленные камни с изображениями оленей и других животных скифской эпохи (IX-III вв. до н. э.), покрытые руникой. Стелы были использованы резчиками рунических эпитафий как готовые формы с обработанной поверхностью. Тексты размещались на наиболее свободной поверхности (Чадамба, Васильев, 1980: 132). К ним относятся оленные камни высотой более 2 метров Е3 (Уюк-Туран) (фото 1), E108 (Уюк-Оорзак I) (фото 2), Е53 (Элегест III) (фото 3).
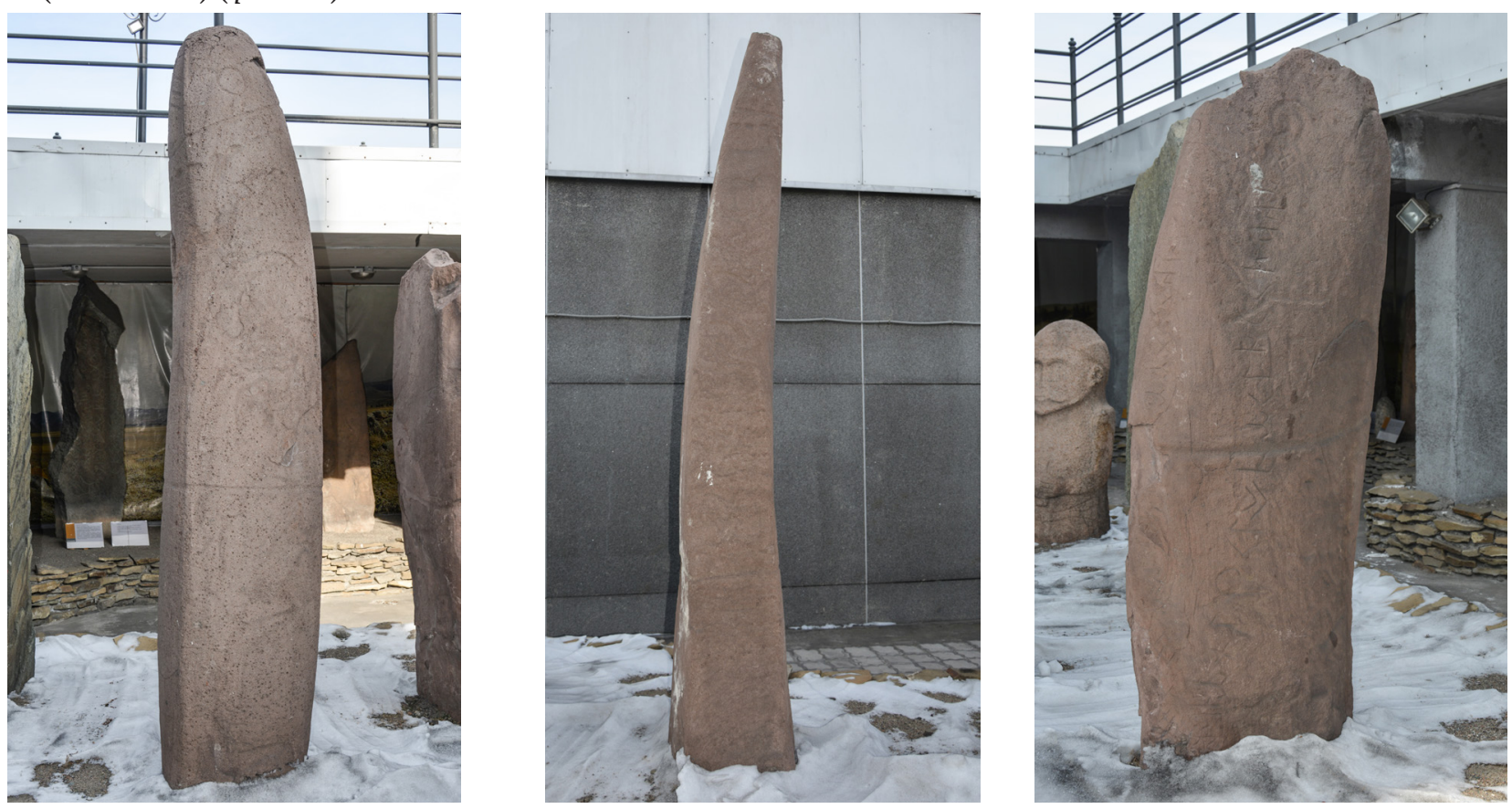

Фото 1-3: 1 - Оленный камень Уюк-Туран (E3); 2. - Оленный камень Уюк-Оорзак (Е108); 3. - Оленный камень Элегест III (E53). Фото А. Куулар, 2019 г.

Photo 1-3: 1. The Uyuk-Turan deer stone (E3); 2. The Uyuk-Oorzak deer stone (E108); 3. The Elegest III deer stone (E53). Photo by A. Kuular, 2019. 


\section{НОВЫЕ ИССЛЕДОВАНИЯ ТУВЫ}

www.nit.tuva.asia

В 1973 г. в тувинский музей доставлен интересный оленный камень скифской эпохи Сайгынская плита (E57) (фото 4), из Южной Тувы. Камень представляет собой в сечении вытянутый прямоугольник из серого песчаника. Находился в местности Борбак-Арыг, вблизи с. Самагалтай Тес-Хемского р. Изображения животных оленей частично утрачены и перекрыты тюркской надписью в две строки, расположенной вертикально.

Памятник был обнаружен Ю. Л. Аранчыном в 1952 г., находился в кургане, раскопанном в 1963 г. М. Маннай-оолом. В фонды тувинского музея стелу передал А. Ч. Кунаа.

В экспозиции музея еще одну группу составляют каменные памятники периода могущества и расивета Монгольской империи (начало XIII - конец XIV вв.). В это время в Туву проникло значительное количество монголоязычных племен (История Тувы, 2001: 162). К этому времени известны ремесленно-хлебопашеские поселения, которые создавались для снабжения монгольской армии хлебом и ремесленными изделиями. В 1956-1962 гг. в Центральной Туве экспедиция Л. Р. Кызласова исследовала остатки шести городов и двух поселений. Это были центры ремесленного производства, не имеющие стен городища: Дон-Терек (30 га), Оймак (40 га), Межегейское (42 га), Могойское (11 га), Элегестское (37,5 га), Эртине-Булакское (44 га), земледельческий хутор близ деревни Сосновки и шахтерский поселок на старых Межегейских угольных шахтах. Раскопки выявили, что большинство сооружений представляют собой жилые, административные и храмовые здания, пагоды и рядовые жилища. Они были построены по общим для всей юго-восточной Азии строительным канонам эпохи Сун (960-1279 гг.) и Юань (1260-1368 гг.), характерным для градостроительной культуры городов Монгольской империи (Кызласов, 1969: 140). Каменотесы этого времени изготовляли жернова для мельниц самых разнообразных размеров (диаметром от 14 см до 2 м), статуи божеств, людей, животных, базы колонн. Посредине центральных площадей городов стояли четырехгранные каменные стелы на каменных черепахах, выполненных из песчаника. На таких стелах вырезались тексты указов. Почти во всех таких городах имелись буддийские храмы, часовни и пагоды, дворы с глинобитными стенами и пристройками, в которых жили буддийские монахи. На городище Оймак найдены обломки гранитной статуи Будды, а также высеченная из песчаника буддийская львинообразная химера, так называемая собака Будды (История Тувы, 2001: 167).

В стеларии музея на данный момент выставлены 14 единиц памятников данного периода - это каменные базы колон - остатки основания здания городищ ДонТерек, Элегест, скульптурный пьедестал для стелы в виде черепахи с утраченной головой из городища Оймак, два каменных льва из урочища Чурумал у р. Баянкольчик. Памятники стояли на могиле монгольской знати возле двух городов Дон-Терек и Оймак. Буддийская химера - «собака Будды», обнаруженная на городище Оймак. Песты для ступы - орудия для размола зерна и рушения проса из городища Оймак. Памятники выполнены из песчаника светлых, лилово-бурых оттенков. Коллекция привезена в музей в 1958-1962 гг. Л. Р. Кызласовым.

В коллекцию каменных памятников музея входят одна из немногочисленных малоизученных камней-плит с тибетскими надписями и на санскрите, датируемые концом XIX - началом XX в., которые свидетельствуют об активном проникновении в Туву буддизма. Их всего - 6 ед. На одной из них, на плоской плите лилового оттенка изображена вырезной техникой буддийская ступа, в самом вверху надпись «хум» на санскрите. На плоскости другой плиты вырезные надписи «ом мани падме хум». В стеларии представлена небольшая плита из белого песчаника, лицевая часть камня полностью покрыта тибетскими надписями, некоторые из них стерты. Где и кем они обнаружены, кому принадлежали - все это нам еще предстоит выяснить.

Таким образом, в тувинском музее хранятся группы каменных памятников различных видов, относящихся к разным временным историческим периодам Тувы. Всего их более 160 единиц, в экспозиции представлены 93. Остальная часть (около 70 камней, а это оленные камни, каменные изваяния, плиты) расположена в хранилище музея.

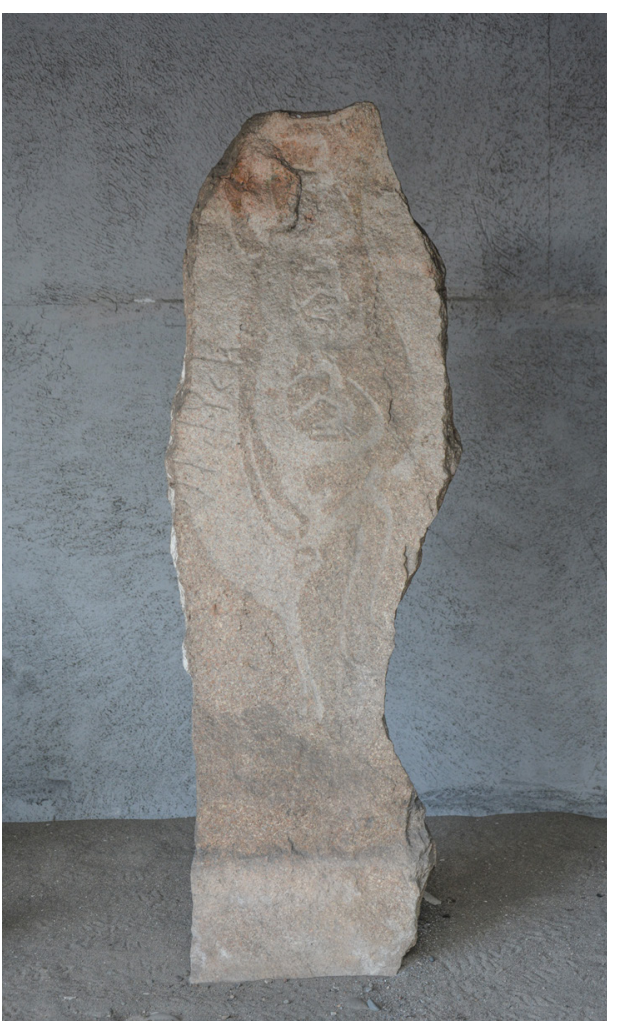

Фото 4. Сайгынская плита (Е57). Фото А. Куулар, 2019 г.

Photo 4. The Saigyn slab (E57). Photo by A. Kuular, 2019. 


\section{Содержание надписей}

Среди коллекции каменных памятников собрания тувинского музея, стелы с руническими надписями (IX-XII вв.) являются именными памятниками, представляющие краткие биографии людей: имя героя, боевые походы, его подвиги, сделанные от имени усопших. Помимо этого, в надписях имеются древнетюркские топонимы, гидронимы и слова, которые сохранились в современных тюркских языках.

Вышеперечисленные темы четко отражены в наиболее известных и интересных памятниках рунической письменности музея.

Приведем текст и перевод надписи памятника из местности Телээ - E46 (фото 5), по данным И. А. Баманова, А. Ч. Кунаа и И. В. Кормушина.

\begin{tabular}{|c|c|}
\hline Чтение: & Перевод: \\
\hline 1. Элим, сизиме, куйда кунчуйум, сизиме. & $\begin{array}{l}\text { 1. Мое государство, - как жаль мне! Мои супруги в } \\
\text { женских покоях, - как жаль мне! }\end{array}$ \\
\hline 2. Өгүне тутук эр эрдеми үчүн элиме тапдым. & $\begin{array}{l}\text { 2. (Я) Эгюнэ-тутук. Во имя доблести мужа-воина я } \\
\text { служил моему государству! }\end{array}$ \\
\hline $\begin{array}{l}\text { 3. Элде экишим, эгритеб, эбим, төрт биң (?) атл } \\
\text { (ар) йылкым. }\end{array}$ & $\begin{array}{l}\text { 3. Мои наложницы, мои верблюды, мой четвероногий } \\
\text { скот }\end{array}$ \\
\hline 4. Буңум йок (Батманов, Кунаа, 1963: 14). & $\begin{array}{l}\text { 4. У меня не (было с ними) печали (Кормушин, 2008: } \\
\text { 137). }\end{array}$ \\
\hline
\end{tabular}

Надпись на массивном четырехгранном столбе неправильной формы, зеленоватого цвета. В 1907 г. впервые памятник был обнаружен Г. В. Гранэ. Происходит из правобережной части Верхнего Енисея, междуречья Телээ и Эжима. Текст впервые опубликован С. Е. Маловым, затем И. А. Батмановым и А. Ч. Кунаа. Эпитафия посвящена правителю области тутуку, по имени Эгюне, который подчеркивает свою добросовестную службу своему государству, прощается с государством и своими супругами, превозносит свое богатство - наложниц, верблюдов, скот, - во всех этих сторонах жизни у него не было печалей, или проблем (Кормушин, 2008: 137).

Другая стела из местности Кызыл-Чыраа - Кызыл-Чыраа II (Е 44), в 1916 г. обнаружена А. В. Адриановым. Впервые ее текст опубликовал С. Е. Малов (Малов, 1951: 78). В 1961 г. стела доставлена в тувинский музей сотрудниками музея и ТНИИЯЛИ (фото 6).

Надпись на большой стеле мелкозернистого песчаника буровато-лилового цвета. Происходит из правобережья Верхнего Енисея, из местности Кызыл-Чыраа, в 50 км западнее г. Кызыла. Герой памятника - Тоган, ему было 40 лет. Он умер еще при жизни отца Арслана. Тоган не занимал крупного административного поста, но был сильным и смелым воином, участник жестоких сражений, уничтожил девять воинов врага, был метким охотником (Кормушин, 2008: 133).

Перевод надписи:

1. Мои могучие руки, мое доблестное сердие, - как жаль, как грустно!

2. Я - тот, кто всегда сражался в жестоких войнах, на проворных ланей я - меткий стрелок. Польза, которую я принес моему божественному государству, -я (лично) убил девять мужей-воинов (врага).

2а. (И вот) я разлучился с этим миром!

3. Мое государство, мой хан, - как жаль, я не насладился! Солнце, луна, - жаль, как грустно!

4. О, мои родственники и родственницы, - как грустно, я разлучился (с вами), как жаль мне! Мой народ Ста (племен) Кюмюлей, - как печально, я разлучился (с тобой)!

5. У меня не (было) избянов в доблестях мужа-воина, (и вот) в сорок лет я расстался (с этим миром)!

6. Я - сын Арслан-Кюлюг-Тирига. Я - Кюлюг-Тоган (там же: 133).

Письменность, созданная в VI в. древними тюрками, не потеряла своей популярности и в период древних кыргызов IX-XII вв., которые также соблюдали традиции и обычаи предшественников. Из надписей нам известно, что в жизни кыргызов IX-XII вв. военная организация также имела огромное значение. Войсками командовали высшие чины военной администрации из представителей каганской династии - министры и управители. Министрами могли быть только представители родовой аристократии - беги. Верховным главнокомандующим был каган (История Тувы, 2014: 146). Во власти кагана на- 


\section{НОВЫЕ ИССЛЕДОВАНИЯ ТУВЫ}

www.nit.tuva.asia

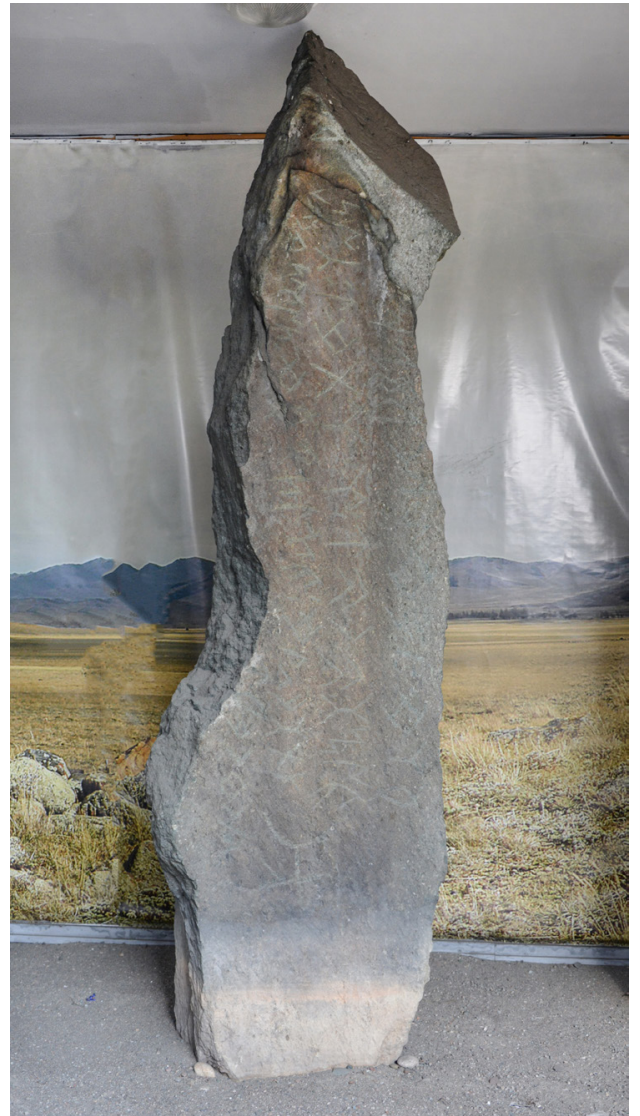

Фото 5. Стела Телээ (Е46) Фото А. Куулар, 2019 г. Photo 5. The Telee stele (E46). Photo by A. Kuular, 2019.

ходились военные силы, решение вопросов войны и мира, назначение высших должностных лиц, он мог казнить и миловать, давать различные награды и пожалования, определять размеры повинностей. Он же был верховным собственником и распорядителем всех земель государства (там же: 148).

Как известно, каганы обращались к Небу с вопросами и мольбами, осуществляя связь Среднего мира с Верхним. Сами каганы могли быть высшими главными шаманами своего народа. Основная часть населения исповедовало местное верование - шаманизм (История Тувы, 2014: 150-151). И сегодня у тувинцев, алтайцев и у хакассов сохранились названия божеств, упоминаемые в древнетюркских надписях - Кок Тенгри - Синее небо, Йер-су - Земля и вода, дух земли и воды, Умай покровительница детей и плодородия (там же: 112).

Стелы с руническими надписями и тамгами входили в погребальный комплекс как часть поминального обряда (там же: 152-153). Как отмечают исследователи, после завоевания Верхнего Енисея енисейскими кыргызами, земли были разделены на примерные территории - шесть крупных уделов, багов. На памятниках енисейской древнетюркской письменности отмечены тамги этих территорий (там же: 136). В надписях также указаны географические названия местностей древнетюркского периода, которых современная народная топонимика Тувы еще хранит комплекс известных названий, в частности гидронимов: Шивилиг (др.-тюрк. Чибилиг), Өөк (др.-тюрк. Эгук), Хем (др.-тюрк. Кем), Алтай (др.-тюрк. Алтай) и др. (там же: 111). В том числе и древн е тю ркски е имена и названия, которые сохранились в современных тюркских языках - Кюлюг-Тириг, Кюни-Тириг (тириг-дириг - живой), Бай опа (Бай-бай - богатый), Чочи Бёри (Бёри - бөрү - волк), Арслан-Кюлюг-Тириг (Арслан - арзылан - лев), Кочгар (Кочгар - кошкар - баран), Кара барс (кара - черный; барс - ирбис), Кюн Чокбе (Кюн - күн -хүн - солнце) (Кормушин, 2008: 90-166).

Как считают специалисты, язык тюркоязычных племен периода Тюркского каганата, дошедший до нас в памятниках древнетюркской и уйгурской рунической письменности, послужил той основой, на которой впоследствии сформировался тувинский язык. По мнению тюркологов, из всех тюркских языков, именно в тувинском языке в наибольшей степени сохранились особенности древнетюркского языка, зафиксированного в орхоно-енисейских письменных памятниках (История Тувы, 2014: 109-110).

Древние тексты указывают на то, что главными вопросами в жизни наших предков были взаимодействие человека с окружающим миром, особая связь поколений, преданность своей земле, своему роду и вечная память о них. В их понимании важными являлись такие понятия, как государство, воины, род, священная земля, синее небо, солнце, вода и т. д. Благосостояние рода, пле-

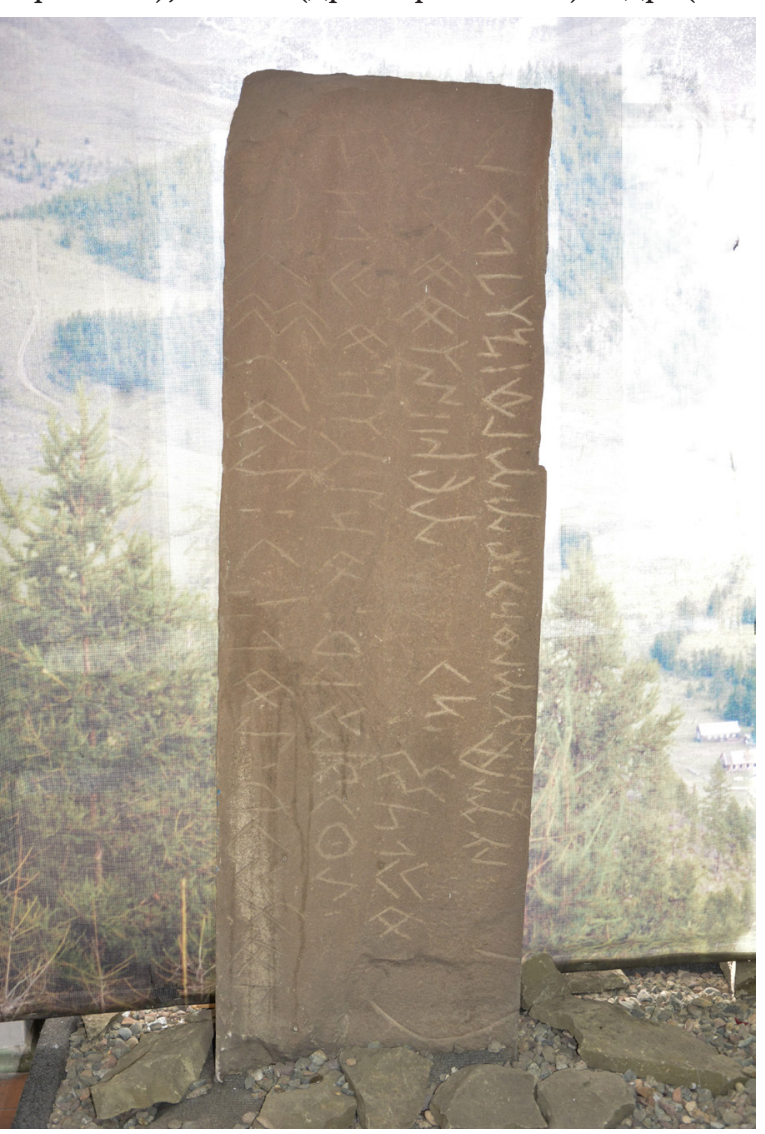

Фото 6. Кызыл-Чыраа II (Е44). Фото А. Куулар, 2019 г. Photo 6. Kyzyl-Chyraa II (E44). Photo by A. Kuular, 2019. 
мени, их настоящее и ближайшее будущее зависело от духов-покровителей определенных местностей. В сохранении природной среды большое значение играли также тотемистические представления, кровно связывающие мир людей с природой. Среди множества духов и божеств в мировоззрении древнего человека главное место занимали синее небо, солнце, земля и вода - көк теңгри, күн, йер, суб - важные составляющие жизни на земле. Поэтому они особо почитались.

\section{Заключение}

Собрание каменных памятников тувинского музея имеет большую научную и культурную ценность, они являются объектами историко-культурологического изучения и популяризации в современном обществе. Благодаря трудам выдающихся ученых, мы можем изучить их, обогатиться новыми знаниями по истории древних предков, передать молодому поколению, формировать у них этническое самосознание. Самой распространенной формой просветительной работы музея является экскурсия. Сотрудниками музея ежедневно проводятся тематические экскурсии по стеларию, где представлены каменные памятники различных исторических эпох. Экскурсии обогащают посетителей знаниями, способствуют восприятию и усвоению увиденного и услышанного.

Коллекция каменных памятников в собрании тувинского музея экспонируется во временном открытом помещении цокольного этажа музея. Представлена только часть коллекции. Посетители чаще всего посещают ее в теплое время года, так как помещение открытое и зимой холодно. Для круглогодичного посещения стелария требуется отдельное помещение. В 2021 г. планируется открыть новое здание рядом с музеем - дворец молодежи со стеларием на цокольном этаже, площадью 430 квадратных метров. Здесь планируется развернуть совершенно новую, современную экспозицию каменных памятников различных исторических эпох Тувы - от древнекаменного века до середины XVIII в.

\section{СПИСОК ЛИТЕРАТУРЫ}

Батманов, И. А., Кунаа, А. Ч. (1963) Памятники древнетюркской письменности Тувы : в 3-х вып. Кызыл : Тувинское книжное издательство. Вып. 1.66 с.

Вайнштейн, С. И. (1974) История народного искусства Тувы. М. : Наука. 224 с.

Васильев, Д. Д. (1983) Корпус тюркских рунических памятников бассейна Енисея. Л. : Наука. 125 с.

Грач, А. Д. (1961) Древнетюркские изваяния Тувы. М. : Изд.-во восточной литературы. 96 с.

Грач, А. Д. (1980) Древние кочевники в центре Азии. М. : Наука. 255 с.

Длужневская, Г. В., Савинов, Д. Г. (2007) Памятники древности на дне тувинского моря. СПб. : ООО «Элексис Принт». 196 с.

Дыртык-оол, А. О. (2006) Музейное дело Тувы. Кызыл : ТывГУ. 85 с.

Дэвлет, М. А. (1990) Листы каменной книги Улуг-Хема. Кызыл : Тувин. кн. изд-во. 120 с.

История Тувы (2001) : в 2 т. 2-е изд., перераб. и доп. / под общ. ред. С. И. Вайнштейна, М. Х. Маннай-оола. Новосибирск : Наука. Т. І. 367 с.

История Тувы (2014) : в 2 т. 2-е изд., перераб. и доп. / под общ. ред. С. И. Вайнштейна, М. Х. Маннай-оола. Кызыл: ОАО Тываполиграф. Т. І. 368 с.

Килуновская, М. Е., Семенов, В. А. (1998) Оленные камни Тувы. Новые находки, типология и вопросы культурной принадлежности. Ч. 1. // Археологические вести. Вып. 5. СПб. : Изд.-во «Дмитрий Буланин». 399 с. С. 143-154.

Килуновская, М. Е. (2009) Собрание каменных изваяний Национального музея им.Алдан-Маадыр Республики Тыва // Наследие народов Центральной Азии и сопредельных территорий: изучение, сохранение и использование. Материалы Междунар. науч.-прак. конф. (9-10.09.2009. Кызыл, Россия) : в 2 ч. / сост. У. Б. Нурзат. Кызыл : КцО Аныяк. Ч. 1.199 с. С. 64-67.

Кормушин, И. В. (1997) Тюркские енисейские эпитафии. Тексты и исследования. М. : Наука. 303 с.

Кормушин, И. В. (2008) Тюркские енисейские эпитафии. Грамматика. Текстология. М. : Наука. 342 с.

Кормушин, И. В. (2009) Тувинский музей - крупнейшее собрание памятников енисейской письменности // Наследие народов Центральной Азии и сопредельных территорий: изучение, сохранение и использование. Материалы Междунар. науч.-прак. конф. (9-10.09.2009. Кызыл, Россия) : в 2 ч. / сост. У. Б. Нурзат. Кызыл : КЦО Аныяк. Ч. 1. 199 с. C. 27-28.

Кызласов, Л. Р. (1969) История Тувы в средние века. М. : Изд.-во Московского ун-та. 210 с. 
Малов, С. Е. (1951) Памятники древнетюркской письменности. М.-Л.: Изд.-во АН СССР. 452 с.

Чадамба, З. Б., Васильев, Д. Д. (1980) Тюркские рунические надписи Уюк-Оорзак // Новейшие исследования по археологии Тувы и этногенезу тувинцев / ред.: А. П. Окладников. Кызыл : Типография г. Кызыла. 167 с. С. $131-143$.

Дата поступления: 01.03.2019 2.

\section{REFERENCES}

Batmanov, I. A. and Kunaa, A. Ch. (1963) Pamiatniki drevnetiurkskoi pis'mennosti Tuvy [Monuments of ancient Turkic writing of Tuva] : in 3 vols. Kyzyl, Tuvan book publishing house. Vol. 1. 66 p. (In Russ.).

Vainshtein, S. I. (1974) Istoriia narodnogo iskusstva Tuvy [A history of folk art of Tuva]. Moscow, Nauka. 224 p. (In Russ.).

Vasil'ev, D. D. (1983) Korpus tiurkskikh runicheskikh pamiatnikov basseina Eniseia [Corpus of Turkic runic monuments of the Yenisei basin]. Leningrad, Nauka. 125 p. (In Russ.).

Grach, A. D. (1961) Drevnetiurkskie izvaianiia Tuvy [Ancient Turkic statues of Tuva]. Moscow, Vostochnaya literatura Publ. 96 p. (In Russ.).

Grach, A. D. (1980) Drevnie kochevniki v tsentre Azii [Ancient nomads in Central Asia]. Moscow, Nauka. 255 p. (In Russ.).

Dluzhnevskaia, G. V. and Savinov, D. G. (2007) Pamiatniki drevnosti na dne tuvinskogo moria [Monuments of antiquity at the bottom of the Tuva sea]. St. Petersburg, OOO «Eleksis Print». 196 p. (In Russ.).

Dyrtyk-ool, A. O. (2006) Muzeinoe delo Tuvy [Museum work in Tuva]. Kyzyl, TuvGU. 85 p. (In Russ.).

Devlet, M. A. (1990) Listy kamennoi knigi Ulug-Khema [Pages from the stone book of the Ulug-Khem]. Kyzyl, Tuvan book publishing house. 120 p. (In Russ.).

Istoriia Tuvy [The History of Tuva] (2001): in 2 vols. $2^{\text {nd }}$ ed. / ed. by S. I. Vainshtein. M. Kh. Mannai-ool. Novosibirsk : Nauka. Vol. 1. 367 p. (In Russ.).

Istoriia Tuvy [The History of Tuva] (2014): in 2 vols. $2^{\text {nd }}$ ed. / ed. by S. I. Vainshtein and M. Kh. Mannai-ool. Kyzyl, OAO Tyvapoligraf. Vol. I. 368 p. (In Russ.).

Kilunovskaia, M. E. and Semenov, V. A. (1998) Olennye kamni Tuvy. Novye nakhodki, tipologiia i voprosy kul'turnoi prinadlezhnosti [Deer stones of Tuva. New finds, typology and cultural issues]. Part 1. Arkheologicheskie vesti, vol. 5. St. Petersburg, Dmitrii Bulanin Publ. 399 p. Pp. 143-154. (In Russ.).

Kilunovskaia, M. E. (2009) Sobranie kamennykh izvaianii Natsional'nogo muzeia im. Aldan-Maadyr Respubliki Tyva [A collection of stone sculptures of the Aldan-Maadyr National Museum of the Republic of Tuva]. In: Nasledie narodov Tsentral'noi Azii i sopredel'nykh territorii: izuchenie, sokhranenie i ispol'zovanie [Heritage of the peoples of Central Asia and adjacent territories: study, conservation and use]. Proceedings of International conference (9-10.09.2009. Kyzyl, Russia) : in 2 parts / ed. by U. B. Nurzat. Kyzyl, KTsO Anyiak. Part 1. 199 p. Pp. 64-67. (In Russ.).

Kormushin, I. V. (1997) Tiurkskie eniseiskie epitafii. Teksty i issledovaniia [Turkic Yenisei epitaphs. Texts and studies]. Moscow, Nauka. 303 p. (In Russ.).

Kormushin, I. V. (2008) Tiurkskie eniseiskie epitafii. Grammatika. Tekstologiia [Turkic Yenisei epitaphs. Grammar. Textology]. Moscow, Nauka. 342 p. (In Russ.).

Kormushin, I. V. (2009) Tuvinskii muzei - krupneishee sobranie pamiatnikov eniseiskoi pis'mennosti [The Museum of Tuva: the largest collection of monuments of the Yenisei writing]. In: Nasledie narodov Tsentral'noi Azii i sopredel'nykh territorii: izuchenie, sokhranenie i ispol'zovanie [Heritage of the peoples of Central Asia and adjacent territories: study, conservation and use]. Proceedings of International conference (9-10.09.2009. Kyzyl, Russia) : in 2 parts / ed. by U. B. Nurzat. Kyzyl, KTsO Anyiak. Part 1. 199 p. Pp. 27-28. (In Russ.).

Kyzlasov, L. R. (1969) Istoriia Tuvy v srednie veka [History of Tuva in Middle ages]. Moscow, Moscow University Publ. 210 p. (In Russ.).

Malov, S. E. (1951) Pamiatniki drevnetiurkskoi pis'mennosti [Monuments of ancient Turkic writing]. Moscow, Leningrad, AN SSSR Publ. 452 p. (In Russ.).

Chadamba, Z. B. and Vasil'ev, D. D. (1980) Tiurkskie runicheskie nadpisi Uiuk-Oorzak [Turkic runic inscriptions of UyukOorzhak]. In: Noveishie issledovaniia po arkheologii Tuvy i etnogenezu tuvintsev [Latest studies on the archaeology of ethnogenesis Tuva and Tuvans] / ed. board: A. P. Okladnikov et al. Kyzyl, Tipografiia g. Kyzyla. 167 p. Pp. 131-143. (In Russ.).

Submission date: 01.03.2019. 